\title{
Beach users' aesthetic and economic evaluation of a "minor change" to the hard engineering coastal defences at Wiseman's Bridge, Pembrokeshire, Wales
}

\author{
F. B. Blakemore, M. Burrell \& S. D. R. Jones \\ Department of Science and Sport, University of Glamorgan, Wales, UK
}

\begin{abstract}
This study evaluated the visual impact of the new hard engineering coastal defences at Wiseman's Bridge, Pembrokeshire, Wales. This beach had existing hard coastal defences, road, car park and dwellings, which may have lead planners' to believe that the change would not impact upon beach users' enjoyment.

However, a change in coastal scenery was expressed by $79 \%$ of those surveyed, using the perceptual approach, whilst the beach classification was unaffected using two checklist models. The beach is primarily utilised by families for children's play and to enjoy the surroundings. Nearly half of the beach users had concerns with regard to the new coastal defences and were willing to pay ( $£ 1.62$ per visit) to fund alternative defence methods for the remaining shoreline. A fifth of respondents were willing to pay ( $£ 1.91$ per visit) for the new defences to be removed and replaced with a more natural method of sea defence. The preferred payment mode in both cases was a car parking fee. Thus, this study has found that even apparently minor changes in scenery impact markedly upon the recreational enjoyment and valuation of the beach experience. Keywords: aesthetics, economic evaluation, willingness to pay, beach users, coastal defences.
\end{abstract}

\section{Introduction}

Due to current predictions of global sea-level rise and growing populations within the coastal zone, coastal defence is an issue that needs to be addressed at 
regional, national and global levels. Governments are being forced to come to terms with the reality of these issues, and subsequent environmental and socioeconomic consequences. One aspect within a suite of UK coastal policy is Shoreline Management Plans (SMPs) these recommend five possible choices for protecting a coastline: hold the line: managed realignment; advance the line; limited intervention; and no intervention [1]. These SMPs also underline the importance of conserving and maintaining the natural environment, including the landscape [2]. The need for maintaining high standards in coastal landscape aesthetics has been outlined in a number of studies [3-6].

Coastal tourism is becoming the largest market sector of the tourism industry and accounts for $44 \%$ of all tourism in Wales [7]. The Welsh economy is therefore heavily dependant on coastal tourism [8]. Scenic quality and natural undeveloped beaches are increasingly being recognised as a major factor in attracting visitors to the Welsh coast. Blakemore and Williams [9] found scenery to be the second most popular reason given for visiting beaches in South-East Wales. Empathetic management of the coast is therefore needed in order to continue to attract visitors to coastal towns and villages.

\subsection{Site location and description}

Wiseman's Bridge is located on the South Pembrokeshire coast of West Wales, UK. Pebble sized clasts chiefly quartzites from the Coal Measure bedrock dominate the upper shore; the lower shore is composed of a sandy shingle mix, varying in composition and rock exposure. The beach has had several stages of coastal defence work over the years. This includes large boulders of Carboniferous Limestone and Dolerite forming a revetment type structure at the foot of the Wiseman's Bridge Inn, a small privately owned sea wall to the east of the Inn, and a large sea wall at the foot of the coastal path that links Wiseman's Bridge and Saundersfoot (pers obs). A car park and private dwellings are situated behind the coastal road that runs parallel to the beach, which has in recent years been overtopped during winter storms and pebbles have been deposited on the road [10]. In addition to this, coastal erosion had threatened to damage and undercut the road. The construction of a solid defence was completed in June 2004. The coastal defences have, in effect, replaced the majority of the berm crest at the top of the beach with an artificial seawall, leaving a limited amount of natural shoreline.

\subsection{Aims of this study}

This study utilised checklist and perceptual approaches to test the hypothesis that the minor changes in the visual impact of the new coastal defences at Wiseman's Bridge would not result in a change of classification in these categorisations. The way the beach is utilised by the public was determined and beach users' economic valuation elicited for the marginal gain in aesthetics, use and enjoyment of the beach with different coastal defences in place. 


\section{Beach evaluation}

The Fuzzy Logic evaluation involved completion of a checklist consisting of 26 parameters (18 Physical; 8 Human) on the beach in question [11]. The value produced by this analysis is used to categorise beaches into five main classes [12]. Comparison of values before and after construction of the coastal defence at Wiseman's Bridge will highlight if any change in scenic quality has arisen according to this approach.

The BARE approach developed by Micallef and Williams [13], recognises five beach bathing area types. These are: Resort, Urban, Village, Rural and Remote. The five main issues of concern regarding beach user preferences and priorities are taken to be: Safety, Water Quality, Facilities, Scenery and Litter.

The perceptual survey took place over a seven-day period from the $19^{\text {th }}$ to the $25^{\text {th }}$ July 2004 at Wiseman's Bridge Beach. This period spanned the first complete week of the school holidays. Tourists were principally targeted because they are an important source of revenue in the area; as a result their opinions are likely to carry weight with coastal planners and developers seeking to promote Pembrokeshire as a tourist destination.

Respondents were chosen randomly, using a probabilistic systematic approach [14], i.e. every $3^{\text {rd }}$ person or group was selected whilst walking along the beach. The nearest person in each group was asked to complete the questionnaire. People in the water were not approached due to the impracticality of hailing them from the shore. A total of 208 questionnaires were completed for full analysis. Sample sizes of 250-500 are usually recommended for open-format CV studies [14]; so the completed survey approached the lower margins of this suggested figure. Rejection rates were low $(<2 \%)$.

\subsection{Methods utilised in the perceptual survey}

Respondents were asked to allocate a score (between -10 and +10 ) for scenic quality using photographs of Wiseman's Bridge, before and after the construction of the coastal defences (Figure 1). The use of photographs as environmental surrogates is widely practised in landscape scenic assessment [15], with many studies suggesting that judgments based on photographs are highly correlated with on site judgements of the same area using rating scales [16-19] or other response formats [20,21].

The photographs were taken at different times of the year ('before' in October 2003 and 'after' in June 2004) resulting a seasonal vegetation difference. Vegetation is considered a key component of landscape beauty [22] therefore these differences may bias results. The increased area of sand after construction, due to natural wave action, may also have influenced the responses. Studies on Italian beaches have found higher valuations for increasing beach area [23].

Two 'willingness to pay' (WTP) scenarios were posed: Respondents were first asked whether they would be willing to pay to fund an alternative method of coastal defence for the remaining one third of the beach, as yet unaffected by the defence works. The question included explanations of alternatives such as maintaining the natural shoreline or managed realignment. 

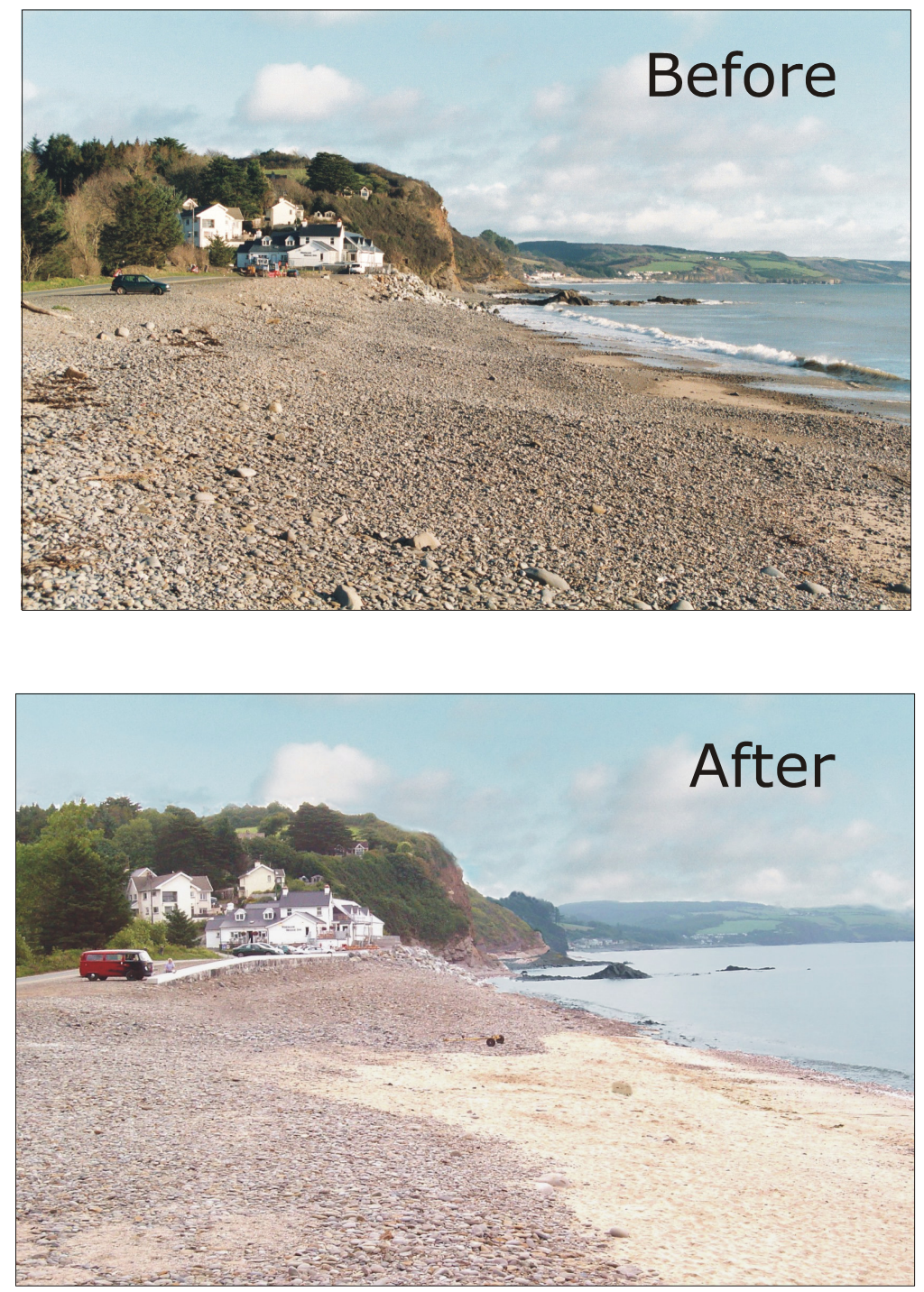

Figure 1: 'Before' and 'after' images of Wiseman's Bridge which respondents were asked to score for scenic quality.

In the second scenario respondents were asked whether they would be willing to pay to fund the replacement of the new defences with an alternative scheme. Four options were described, supplemented by diagrams: revert to natural shoreline, removal of defences with beach replenishment, removal of defences with managed realignment and 'don't know/unsure'. No guidance on costs or on effectiveness of these alternatives was given as the aim was to consider aesthetic and beach use valuation only. 
Both scenarios asked respondents which method of payment they considered most appropriate. Respondents were also asked to state how much they considered a reasonable contribution to pay per visit. No guide price was given as to what would be a reasonable charge for use of the beach in order to avoid influencing respondents and to eliminate starting point bias [24].

\section{Results and discussion}

The mean age of respondents was 48 years, with slightly more females being interviewed than males (57\%). Females have been better represented than males in similar beach studies, such as that of Nelson and Botterill [25] (60\% female respondents), who attributed this trend to mothers visiting the beach with their children.

Respondents were mainly tourists (87\%), the largest contingent $(56 \%)$ travelling from England. Visitors from South Wales formed the second highest proportion of beach users (24\%). The small number of European visitors and a lack of tourists from further a field are consistent with the findings of Morgan ${ }^{5}$, and reaffirm the notion that the South Wales coast is not a significant international tourist destination.

Day-visitors accounted for $13 \%$ of respondents. Most day-visitors, were encountered during the weekend, when they are less likely to be working. The majority of visitors were staying in the area for a week $(49 \%)$ or a fortnight $(23 \%)$.

\subsection{Beach use at Wiseman's Bridge}

The most popular priority stated for visiting the beach was 'For the children to play' (35\%) indicates the importance of Wiseman's Bridge as a family beach. The second most popular priority (25\%) for visiting Wiseman's Bridge was to 'enjoy the surroundings', indicating its aesthetic importance and that recreation can be an emotional as well as physical experience [26]. Walking was also rated highly (23\%), with many respondents visiting Wiseman's Bridge to walk their $\mathrm{dog}$, to stroll along the beach or to walk the coastal path. Less frequently given reasons for visiting the beach included swimming, sunbathing and water sports. Weather was a factor affecting these activities, as it was generally poor over the week of the survey. Swimming may be slightly under represented because visitors actively swimming were not approached.

\subsection{Check list assessments}

The majority of physical and human Fuzzy logic parameters were allocated high scores. The lowest scoring human parameters were access type (no buffer zone/light traffic) and utilities (two utilities present - sea wall and revetment). As sea walls and rock protection/revetments were previously present at Wiseman's Bridge, the building of the new defences did not alter the scoring of these parameters. These were the only parameters likely to change as a result of the building of the defences: The Fuzzy Logic assessment therefore indicates no 
change in scenic quality before and after construction of the sea defences. The assessment gave a value of 0.77 , placing it in class 2 an attractive natural site with high landscape value.

Wiseman's Bridge does not meet the BARE specification to be a "village": as it is not associated with a small but permanent population reflecting access to organized but small-scale community services (such as a primary school(s), religious centre(s) and shop(s). Wiseman's Bridge best fits a "rural area" as it is located outside the urban/village environment. This classification was unaffected by the minor changes made to the beach defences. The changes to the beach defences only affects one of the five issues of concern regarding beach user preferences and priorities, that of Scenery. This is only marginally changed and so the BARE approach does not register the impact of the changes made at Wiseman's Bridge.

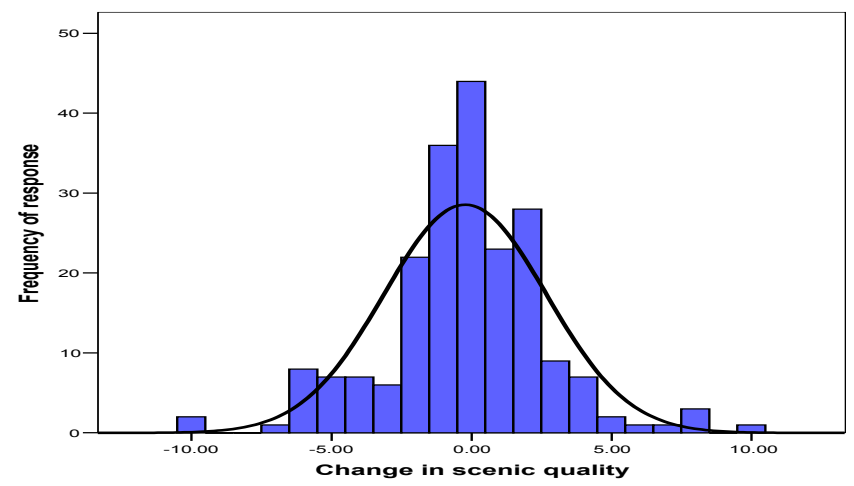

Mean $=-0.2163$
Std. Dev. $=2.90532$
$N=208$

Figure 2: Variance in scenic quality ratings at Wiseman's Bridge as a result of construction of the new coastal defences.

\subsection{Public perception of visual impact}

Slightly more (43\%) respondents gave Wiseman's Bridge a higher scenic quality score before construction of the new defences than $(36 \%)$ after, however a considerable number believed scenic quality had not changed $(21 \%)$. Respondents generally perceived little change in scenic quality, $73 \%$ changed by 2 points or less on a scale of minus 10 to plus 10 , with a variation of zero (no change) being the most frequent.

This high central tendency coupled with a constrained range (Figure 2) deviates from a normal distribution (Kolmogorov-Smirnov test $Z=2, p=0.001$ ). A number of studies illustrate correlation between natural landscapes and higher aesthetic quality rating $[4,18,27,28]$. In the study the 'after' photograph was taken shortly following completion of the defences, with rock armouring at the base of the sea wall concealed by beach material, giving the defences a new and 'tidy' appearance (Figure 1). This picture also displayed a greater area of sand on the beach, which is likely to have improved the scores for the after photograph [23]. Results may indicate a higher preference for the pre-defence situation if the 
study is repeated using photographs taken a year or longer after construction, when the wall will have sustained inevitable wear and tear, and the rock armouring may be exposed.

Respondents were able to view the after scenario in three dimensions on-site as well as via a landscape surrogate (i.e. the photograph). Differences between depth of field of vision of photographs and human perception are considered by Bernaldez et al. [28] to be a serious limiting factor when comparing photo based and on-site visual assessments. This may possibly be a factor reducing respondents change in opinion between the two scenarios.

\subsection{Contingent valuation; beach users 'willingness to pay'}

The questionnaire revealed that $49 \%$ of respondents were willing to pay to use Wiseman's Bridge in order to fund an alternative method of coastal defence for the remainder of the beach, as yet unaffected by the sea wall. Tourists were more likely than day-visitors to express WTP to use the beach (tourists: 51\% WTP; day-visitors: $35 \%$ WTP). This may be because local day-visitors use the beach more often than tourists and would have to pay frequently for a commodity that is presently free of charge. A charge for beach use may drive the local population to other areas. In contrast, tourists expect to incur costs for goods and services whilst on holiday. However, tourists are more likely to visit several places in one day so charges at each location may result in high cumulative costs. Therefore tourists visiting several areas may be less likely to visit Wiseman's Bridge if a charge is introduced for beach use. The mean value that the $49 \%$ of respondents who were WTP for beach use gave as a reasonable charge was $£ 1.62$. This is similar to the values found to maintain beaches in other published work such as Blakemore and Williams [29] ( $£ 1.03$ per adult per visit) and King [30] (£1.78). No unreasonably high (protest) values were received (maximum value of $£ 3.50$ per day, one respondent).

In this study, chi-squared analysis indicated that there was no significant difference in WTP of respondents due to income level: Chi-squared $=4.67, \mathrm{p}=$ $0.458 \mathrm{df}=5$ and Cramer's $\mathrm{v}=0.153$. Comparison of each pair of income classes (classes as in figure 3) also indicated no significant differences in WTP.

The most popular method of payment for beach use was a car-parking fee $(85 \%)$. The majority of beach users had arrived by car $(66 \%)$. A number of respondents stated that they were visiting Wiseman's Bridge because; unlike nearby coastal resorts (Tenby and Saundersfoot), there is no car-parking fee. If this mode is used to raise revenue either: a daily parking ticket for any car park or charging an hourly rate for parking. would enable tourists to travel to several locations without paying excessive charges.

Respondents were also asked if they would be willing to pay to remove the present coastal defences and replace them with an alternative solution. This question received less support than the first scenario; only $21 \%$ of respondents expressed WTP. Comments made by respondents included: A general consensus amongst respondents was that the hundreds of thousands of pounds spent on the 


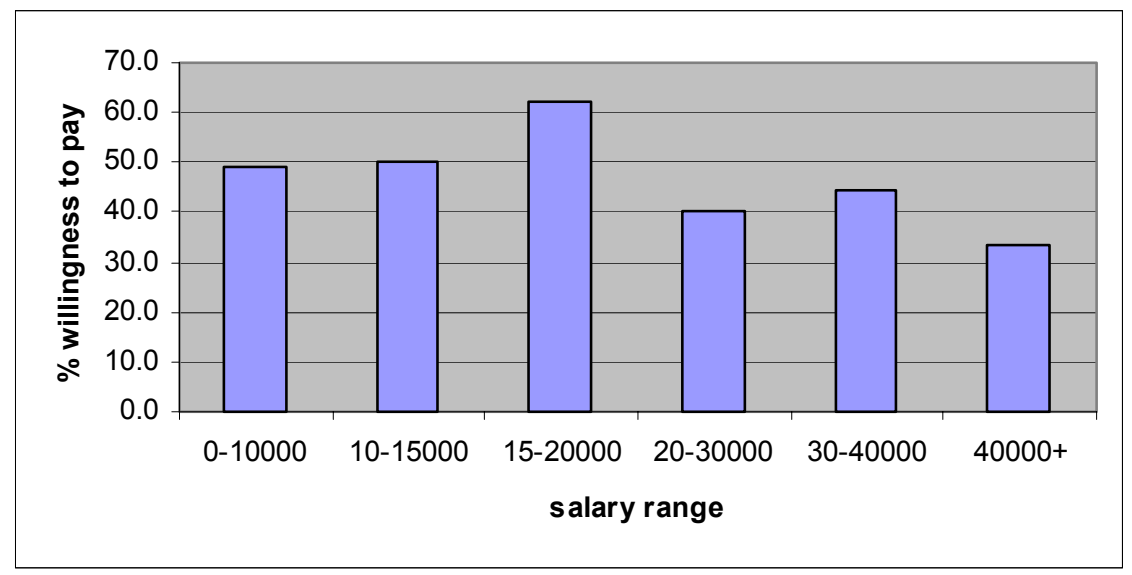

Figure 3: $\quad$ WTP for an alternative defence for remainder of the beach as a function of salary range.

structure should not be wasted and the best strategy now was to maintain the defences; many respondents did not believe the present defence was the best option, but were not concerned enough to pay to fund an alternative; others felt that Pembrokeshire County Council had taken this action because it was the only and or best option for defence of the road. The $21 \%$ of respondents WTP to remove the sea wall had a very strong opposition to the new defences. This is reflected in the higher amount they were WTP on average per trip (£1.91), compared to those WTP to fund an alternative solution for just the remainder of the beach (£1.62). The preferred method of payment was once again car-parking fees $(76 \%)$. A similar proportion of both tourists and locals were WTP for this second scenario. The majority of respondents who expressed WTP to fund a replacement strategy considered either managed realignment $(43 \%)$ or Beach replenishment (39\%) to be the most suitable alternative option.

\section{Conclusions}

Wiseman's Bridge has been shown to be popular among families, with the most common reason for visiting the beach being 'for the children to play'. In conformity with other work, i.e. Morgan ${ }^{5}$ and Blakemore and Williams [31,32], aesthetic quality has also proved to be important to beach users as 'enjoying the surroundings' was the second most popular reason for visiting Wiseman's Bridge. Coastal planners must be aware that recreation can be an emotion rather than an action performed and that the building of coastal defences can affect passive beach use of this kind.

This study suggests the new coastal defences at Wiseman's Bridge may have had a detrimental effect on the aesthetic quality of the coastal environment

The Fuzzy Logic approach developed by Ergin et al. $[11,12]$ and the BARE system of Micallef and Williams [13] were unable to detect a change in scenic 
quality. This underlines the fact that affect on scenic quality was marginal. Thus, the concerns and negative responses obtained in this study may be magnified in a situation where hard engineering defences are constructed on a more natural beach.

The Contingent Valuation Method has demonstrated that around half of Wiseman's Bridge beach users are 'willing to pay' to preserve the remaining area of the upper beach from extension of the new defences. If a charging scheme was established for use of the beach, a car-parking fee is likely to cause least offence. The form of the parking fee introduced should not penalise tourists making various trips per day nor cause locals to use adjacent free beaches.

The second scenario, in which revenue generated would fund the replacement of the seawall with an alternative, highlighted that approximately a fifth of beach users felt a strong opposition to the defences, reflected in their higher valuation, $£ 1.91$ compared with $£ 1.62$ in the first scenario. Again this response is based on a marginal change to the pre-existing sea defences. Managed realignment, which is considered environmentally and economically viable under the Carmarthen Bay Shoreline Management Plan, was chosen by those respondents WTP as the most suitable alternative to the present defence. This demonstrates a degree of public competency in coastal defence issues and should encourage planners to allow the public to take a more active role in coastal defence decision-making.

Economic demand, beach use and public opinion regarding aesthetic impact are important when planning construction of coastal defences, especially in areas of scenic beauty, reliant on tourism such as Wiseman's Bridge

\section{References}

[1] DEFRA (2001) Shoreline Management Plans - A guild for coastal defence authorities. DEFRA Publications.

[2] ECUS (2003) Guidance on coastal defence in relation to their landscape and visual impacts. CCW Contract Science Report No. 531. Appleton, J. H. (1975) Landscape evaluation: the theoretical vacuum. Trans. Inst. British Geography 66, p 120-123

[3] Young, C., Barugh, A., Morgan, R. \& Williams, A. T. (1996) Beach user perceptions and priorities at the Pembrokeshire Coast National Park, Wales, U.K. In: Partnership in Coastal Zone Management, Taussik, J. \& Mitchell, J. (eds). Samara Publishing Ltd., Cardigan.

[4] Morgan, R. \& Williams, A. T. (1999) Video panorama assessment of beach landscape aesthetics on the coast of Wales. Journal of Coastal Conservation 5, p 13-22.

[5] Morgan, R. (1999) Preferences and priorities of recreational beach users in Wales, U.K. Journal of Coastal Research 15(3), p 653-667.

[6] Somerville, S. E., Miller, K. L. \& Mair, J. M. (2003) Assessment of the aesthetic quality of a selection of beaches in the Firth of Forth, Scotland. Marine Pollution Bulletin 46(9), p 1184-1190.

[7] WTB (2003) Domestic (UK) tourism to Wales 2003 [online]: www.wtbonline.gov.uk 
[8] Botterill, D., Owen, R. E., Emanuel, L., Foster, N., Gale, T., Nelson, C. \& Selby, M. (2000) Perceptions from the periphery; the experience of Wales. In: Aspects of Tourism in Peripheral Areas, Brown, F. \& Hall, D. (eds). Channel View Publications, Clevedon, p 7-38.

[9] Blakemore, F. B. \& Williams, A. T. (1998) Public valuation of beaches in South East Wales, U.K. Shore and Beach 4, p 18-23.

[10] Royal Haskoning (2003) Technical Report for Pembrokeshire County Council (unpublished).

[11] Ergin, A., Karaesmen, E., Williams, A. T., Micallef, A., Karakaya, S. T. \& Dedeoolu, M. R. (2003) Coastal scenery evaluation: applications of Fuzzy Logic mathematics at Turkish sites. COPEDEC VI, Paper no. 164, Colombo, Sri Lanka

[12] Ergin, A., Karaesme, E., Micallef, A. \& Williams, A. T. (2002) A new methodology for evaluating coastal scenery: fuzzy logic systems. AREA.

[13] Micallef, A. and Williams, A.T. (2004) Application of a novel approach to beach classification in the Maltese Islands. Ocean \& Coastal Management. 47, Issues 5-6, 2004, Pages 225-242. Morgan, R. (1998) A novel, userbased rating system for tourist beaches. Tourism Management 20, p 393410.

[14] Bateman, I. J., Carson, R. T., Day, B., Hanemann, M., Hanley, N., Hett, T., Jones-Lee, M., Loomes, G., Mourato, S., Ozdemiroglu, E., Pearce, D. W., Sugden, R. \& Swanson, J. (2002) Economic Valuation with Stated Preference Techniques: A Manual. Edward Elgar, Cheltenham.

[15] Hull, R. B. \& Stewart, W. P. (1992) Validity of photo-based scenic beauty judgments. Journal of Environmental Psychology 12, p 101-114.

[16] Shuttleworth, S. (1980) The use of photographs as environmental presentation medium in landscape studies. Journal of Environmental Management 11, p 61-76.

[17] Nausser, J. I. (1982) Framing the landscape in photographic simulation. Journal of Environmental Management 17, p 1-16.

[18] Zube, E. H., Simcox, D. E. \& Law, C. S. (1987) Perceptual landscape simulations: history and prospect. Landscape Journal 6, p 62-80.1

[19] Bosselmann, P. \& Craik, H. K. (1989) Perceptual simulation of environments. In: Methods in Environmental and Behavioural Research, Bechtal, R., Marans, R. \& Michelson, W. (eds). Van Nostrand Reinhold, New York. $p$ 162-190.

[20] Shafer, E. L., Hamilton Jr., J. F. and Schmidt, E. A., (1969). Natural resource preferences: a predictive model. Journal of Leisure Res. 1, p 1-19.

[21] Palmer, J. F. (2004) Using spatial metrics to predict scenic perception in changing landscape: Dennis, Massachusetts. Landscape \& Urban Planning 69(2-3), p 201-218.

[22] Appleton, J. H. (1975) Landscape evaluation: the theoretical vacuum. Trans. Inst. British Geography 66, p 120-123.

[23] Polomé, P., Marzetti, S. and Van der Veen, A. (2005) Economic and social demands for coastal protection, Coastal Engineering, 52 (10-11), pp. 81940 . 
[24] Knetsch. J. L. (1993) Environmental evaluations: some practical problems of wrong questions and misleading answers. Resource Assessment Commission, Australian Government Service. Occasional paper No. 5, p 26.

[25] Nelson, C. \& Botterill, D. (2002) Evaluating the contribution of beach quality awards to the local tourism industry in Wales - the Green Coast Award. Ocean \& Coastal Management 45(2-3), p 157-170.

[26] Torkildsen, G. (1992) Leisure and Recreation Management ( $3^{\text {rd }}$ Edition). Chapman \& Hall, London

[27] Fines, K. D. (1968) Landscape evaluation: a research project in East Sussex. Regional Studies 2, p 41-55.

[28] Bernaldez, F. G., Ruiz, J. P., Benayas, J. \& Abello, R. P. (1988) Real landscapes versus photographed landscapes: preference dimensions. Landscape Research 13(1), p 10-11.

[29] Blakemore, F. B. and Williams A. T. (2007) British tourists' valuation of Turkish beaches using Contingent Valuation and Travel Cost Methods. $J C R$, in press.

[30] King, O. H. (1995) Estimating the value of marine resources: a marine recreation case. Ocean \& Coastal Management 27(1-2), p 129-141.

[31] Blakemore, F. B., Williams, A. T. \& Ozhan, E. (2000) Tourist evaluation of Olu Deniz beach (Turkey) using Contingent Valuation and Travel Coast approach. World Leisure 4, p 48-55.

[32] Blakemore, F. B. \& Williams, A. T. (2002). A comparison of tourist evaluation of beaches in Malta, Romania and Turkey. World Leisure 2, p 29-41. 